\title{
"Economia criativa" como categoria nativa: a atuação dos economistas e as condições de legitimação de um novo recurso de poder
}

\author{
Elder Maia Alves' \\ Bruno Gontyjo do Couto²
}

\section{Resumo}

Nas últimas duas décadas os temas economia criativa, indústrias criativas e cidades criativas serviram como lastro técnico e operacional para a formulação e execução de uma série de políticas de desenvolvimento econômico. Os principais artífices dessa profusão, legitimação e acúmulo de poder foram os economistas, os administradores e os teóricos das escolas de negócios em estreito interesse com os governos nacionais e as agências transnacionais do sistema ONU (Organização das Nações Unidas). Esse processo somente se tornou possível em razão dos atravessamentos entre as sociedades pós-industriais de serviços, a expansão da economia do conhecimento e a contundente digitalização dos mercados culturais. A conjugação desses aspectos produziu uma aproximação estrutural entre o domínio estético-simbólico e o econômico-tecnológico, resultando no aparecimento de categorias nativas como economia criativa. Essas categorias não dispõem de potencial descritivo e analítico que lhes permitam explicar as novas relações entre os dois domínios, mas são elas mesmas resultado destas.

Palavras-chave: Economia criativa. Mercados culturais-digitais. Categoria nativa. Economistas.

\footnotetext{
1 Professor Associado do Programa de Pós-graduação em Sociologia da Universidade Federal de Alagoas (UFAL). Doutor em Sociologia pela Universidade de Brasilia. Contato: epmaia@hotmail.com.

2 Doutorando no Programa de Pós-graduação em Sociologia da Universidade de Brasília. Mestre em Sociologia pela Universidade de Brasilia. Contato: brunogcouto@gmail.com.
}

\section{$(\infty))$ EY}

Direito autoral e licença de uso: Este artigo está licenciado sob uma Licença Creative Commons. Com essa licença você pode compartilhar, adaptar, para qualquer fim, desde que atribua a autoria da obra, forneça um link para a licença, e indicar se foram feitas alterações. 


\section{Introdução}

Ao longo das duas últimas décadas, um processo de aproximação estrutural entre os domínios estético-simbólico e econômico-tecnológico ${ }^{3}$ ocorreu, produzindo uma nova constelação sócio-histórica ${ }^{4}$. A rigor, esses domínios não estavam inteiramente afastados, pois as relaçóes entre arte, técnica e mercado existem pelo menos desde a segunda metade do século XIX, aprofundando-se ainda mais no decurso do século XX. Contudo, uma das marcas históricas das sociedades modernas fora justamente a separação e diferenciação entre esses dois domínios. Ao contrário de outros momentos, quando categorias analíticas como a de indústria cultural cunhada por Adorno e Horkheimer (1985) na década de 1940, a de materialismo cultural proposta por Raymond Williams (2007) nos anos 1980 ou mesmo a ideia de economias de signos e espaços de Lash e Urry (1993) na década de 1990, no presente as Ciências Sociais não dispóem de uma categoria descritiva e analiticamente potente com capacidade para traduzir as novas relaçôes entre os domínios estético-simbólico e econômico-tecnológico.

Atualmente, ocorre justamente o contrário. As categorias que emergiram nas últimas décadas com o fito de traduzir essa aproximação estrutural são elas mesmas resultado e efeito do processo em questão. Tratamse das categorias-força de indústrias criativas, economia criativa e cidades criativas, que foram construídas e disseminadas por governos, empresas e organismos transnacionais. Como assinala Elias (1994), toda categoria é um símbolo-conceitual que condensa valores, interesses e autoimagens específicas. Contudo, essas categorias não são conceitos forjados de acordo com os princípios do trabalho intelectual das Ciências Sociais, manuseados segundo os imperativos empíricos da pesquisa, mas sim categorias nativas ${ }^{5}$,

3 Os termos estético-simbólico e econômico-tecnológico, aqui apresentados como esferas da vida social apartadas uma da outra, dizem respeito respectivamente: i) ao campo cultural no seu sentido restrito e na sua configuração moderna, enquanto espaço relativamente autônomo de produção de bens simbólicos. Ou seja, os campos artístico e intelectual; ii) ao campo econômico, enquanto espaço de produção de mercadorias (sobretudo, bens materiais).

4 Aqui, a ideia de constelação sócio-histórica remete aos trabalhos de Max Weber (200I) e Norbert Elias (1994), correspondendo basicamente ao sentido de que um determinado conjunto de eventos históricos pode ser pensado enquanto uma "configuração" cujo estado resulta dos seus elementos integrantes (eventos) e das relações que eles estabelecem entre si.

5 O termo "categoria nativa" aqui empregado diz respeito à diferenciação proposta por Pierre Bourdieu entre categoria nativa e categoria analítica, sendo a primeira vinculada ao senso comum, ao conhecimento prático 
engendradas em meio a outros critérios, interesses e usos. Essas categorias-força nasceram inclinadas a uma aplicação governamental e corporativa prática, foram ajustadas às demandas das novas políticas de desenvolvimento econômico elaboradas no âmbito do processo de consolidação das sociedades pós-industriais de serviços e da economia do conhecimento.

Cada uma dessas categorias-força traz em si um sistema de interesses, regimes de usos e uma teia institucional específica. Com efeito, importa muito menos localizar e explorar as propriedades analíticas, conceituais e teóricas internas a cada uma dessas categorias, e muito mais descrever e explicar o sistema de usos político-econômicos nos quais elas estão diretamente inscritas. Parte desse sistema de uso decorre do interesse que essas categorias-forças despertaram junto à comunidade científica dos economistas, administradores e teóricos das escolas de negócios, muitos dos quais se especializaram no tema e instauraram esse debate em diversos lugares do mundo ao longo das últimas duas décadas. Essas categorias-forças foram cunhadas e/ou aprimoradas por um seleto grupo de economistas em estreita cooperaçáo com governos nacionais, escolas de negócios e agências transnacionais. Pertencem a esse grupo autores como Richard Chaves, David Thorsby, John Howkins, Richard Florida, John Hartley, Paul Tolilla e François Benhamou.

Para compreender como, por que e sob que condiçóes esse seleto grupo de economistas conquistou poder técnico-operacional e, por conseguinte, as categorias de indústrias criativas, economia criativa e cidades criativas foram forjadas, legitimadas e aplicadas é preciso inseri-las em um movimento sociológico mais abrangente, que passa, incontornavelmente, por três caminhos: 1) o aumento da relevância econômica do setor de serviços nas principais economias do mundo, especialmente os serviços de informação, comunicação, educação, arte, entretenimento e cultura; 2) a consolidação das chamadas economias do conhecimento e a centralidade dos setores de serviços dedicados à pesquisa, inovação e à proteção da propriedade intelectual; 3) a digitalização e expansão dos mercados culturais.

que é construido pelos membros de uma sociedade de forma espontânea, e a segunda vinculada ao conhecimento científico, elaborado a partir do trabalho reflexivo, sistemático e submetido às regras da vigilância epistemológica (BOURDIEU, 200I). 
É preciso assinalar que esses caminhos ocorreram de maneira sincrônica, se retroalimentaram e estabeleceram estreitas interdependências entre si. A relevância empírica desses processos impóe que este trabalho dedique três seçóes a cada um deles, relacionando-os com vistas a sustentar a hipótese que instiga este trabalho, qual seja: nas últimas duas décadas, as políticas públicas de desenvolvimento econômico formuladas e executadas sob a inspiração da categoria-força de economia criativa trouxeram as organizaçôes estatais para o centro dos mercados culturais-digitais, e, ao fazê-lo, simultaneamente, criaram um novo regime de competência técnico-científica, exercido pelos economistas-consultores, cujo trabalho operacional (a criação de índices, indicadores, modelos teóricos e métricas) fez do conceito de economia criativa e toda sua família conceitual uma categoria nativa, um novo regime discursivo, e não uma construção analítica.

\section{A consolidação das sociedades pós-industriais de serviços}

Conforme constata Bell (1977), em 1870 o emprego agrícola representava $47 \%$ da força total de trabalho nos EUA, em 1970, um século após, o emprego agrícola representava apenas 3\% do total da força de trabalho empregada. Por outro lado, durante o mesmo período, o emprego no setor de serviços saiu de $26 \%$ para $60 \%$ do total da força de trabalho empregada. Seguindo esse diapasão, entre as décadas de 1920 e 1970, ocorreu uma redução substantiva no contingente de trabalhadores empregados na indústria extrativa (mineração e agricultura), saindo de 28,9\%, em 1920, para 4,5\%, em 1970. No rastro do diagnóstico de Bell, no transcorrer dos anos de 1970 e 1980 o processo de desindustrialização das principais economias do globo se acentuou. É possível assinalar que, se antes o movimento de expansão paulatina do setor de serviços estava encerrado aos limites de países como Estados Unidos e Inglaterra, no decurso do período aludido cada vez mais se constataram sucessivas reduçóes da participação da indústria e do setor industrial na composição do Produto Interno Bruto (PIB) das maiores economias do globo. As séries históricas de países como o Brasil demonstram a redução progressiva da indústria na composição do PIB. Como evidencia o Gráfico 1, a seguir, ocorreu um crescimento regular do valor adicionado do setor de serviços à economia brasileira entre o primeiro trimestre de 2000 e o primeiro trimestre de 2017. Nesse último 
trimestre, o setor de serviços correspondia a 75,2\% do valor adicionado ao PIB brasileiro, ao passo que o setor industrial adicionou $21,4 \%$ e o setor agropecuário, 3,4\%.

Gráfico I - Participação dos setores da economia no PIB - Brasil

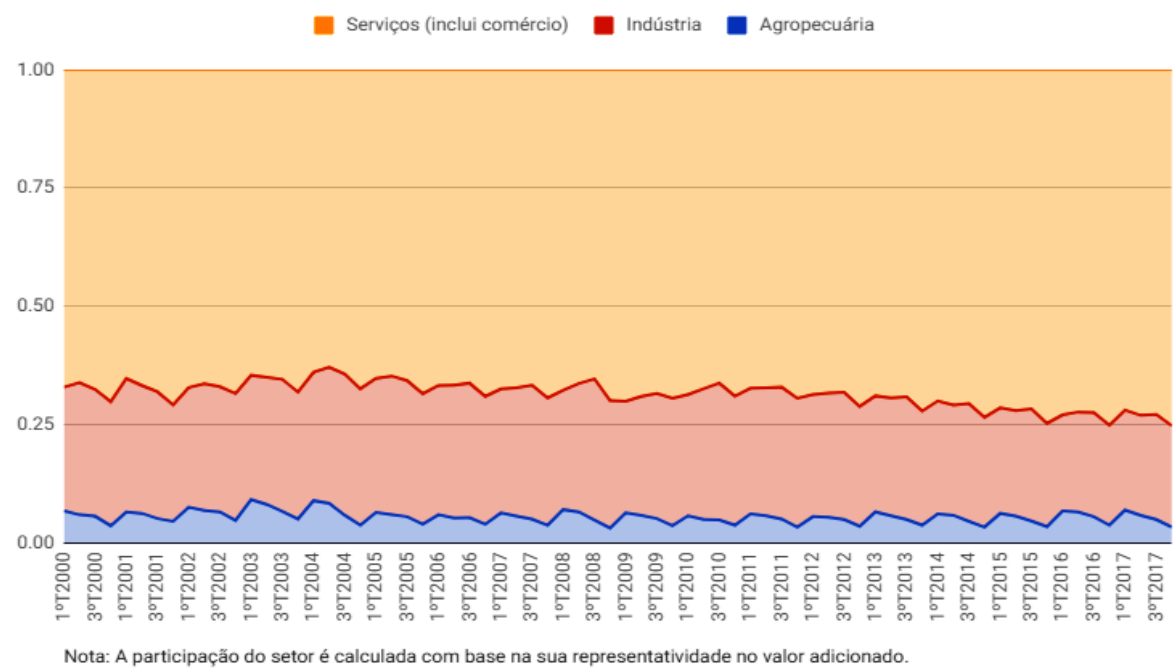

Fonte: SEBRAE (20/8).

$\mathrm{O}$ valor adicionado pode ser conjugado a outros indicadores. Por exemplo, em 1984 o grau de participação da indústria de transformação no PIB brasileiro chegou a 36\%, maior percentual entre 1947 e 2013. Conforme assinala o Gráfico 2 (abaixo), em 2013, menos de 30 anos depois, a participação da indústria de transformaçáo no PIB brasileiro caiu para 10\%. Segundo o Instituto de Pesquisa Econômica Aplicada (2017), doravante IPEA, a indústria de transformação abriga quatro estágios de intensidade tecnológica: baixa, média-baixa, média-alta e alta. Os segmentos, setores e produtos que portam baixa e média-baixa intensidade tecnológica são os produtos industrializados ou que passam por processos de industrialização e são comercializados contendo baixo valor agregado, como commodities, indústria química, indústria de base e pesada. Já os setores e produtos situados como de média-alta e alta intensidade tecnológica referem-se à sofisticada infraestrutura de softwares, servidores e redes de armazenamento 
de dados, notadamente os dispositivos que integram a computação em nuvem, a inteligência artificial, as redes de comunicação e informação on-line. Destacam-se, entre esses, os serviços de armazenamento e gerenciamento de dados, as plataformas de tecnologia da informaçáo e comunicação, os serviços culturais-digitais de música, audiovisual, editorial e games. Vê-se que, mesmo nesse último caso, são necessários componentes industriais mínimos de infraestrutura física e operacional, o que estabelece uma interface estreita entre a vanguarda tecnológica, aspectos industriais sofisticados (a miniaturização e a nanotecnologia) e o diferenciado setor de serviços. No limite, pode-se afirmar que o caráter físico dos componentes industriais mais sofisticados, que portam média-alta e alta intensidade tecnológicas, refere-se muito mais a uma espécie de tecnologização, que não pode (ainda) prescindir da dimensão física, mas que a ultrapassa em muito.

Gráfico 2 - Brasil - grau de industrialização e renda per capita (1947-2013)

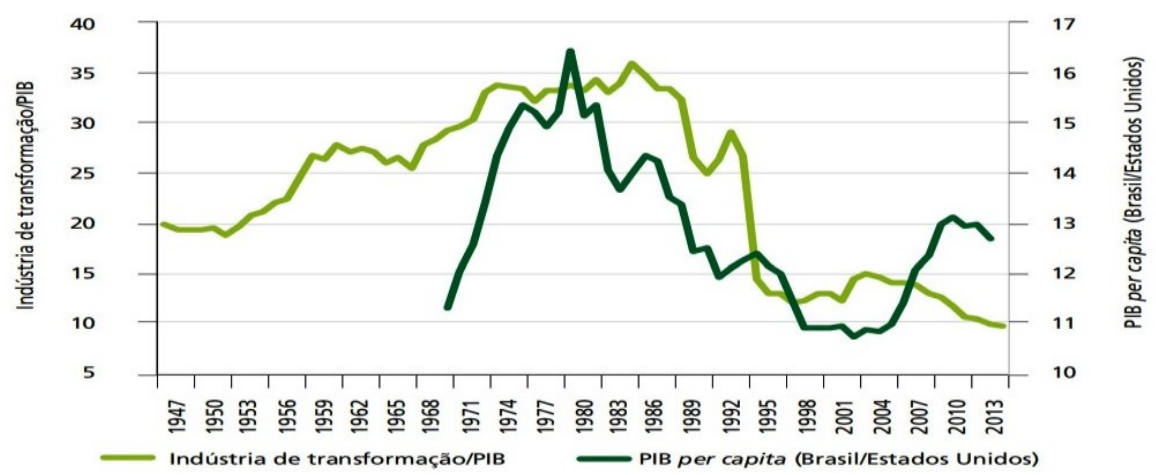

Fonte: IPEA (20/4b)

É preciso assinalar que a redução geral da participação do setor industrial no PIB global, acompanhado da expansão e do aumento da participação do setor de serviços no PIB e, por conseguinte, da regular desindustrialização que fez emergir as sociedades pós-industriais não constitui um mero pano de fundo. A consolidação das economias pós-industriais foi um fenômeno de impacto decisivo, que pressionou para que, na década de 1990, os economistas entrassem com todo vigor no debate envolvendo as relaçóes entre o domínio estético-simbólico e o domínio econômico-tecnológico. 


\section{A consolidação da economia do conhecimento e da inovação}

O segundo caminho aludido diz respeito ao processo de consolidação das chamadas economias do conhecimento. No entanto, não haveria a consolidação da economia do conhecimento na década de 1990 sem a profusão dos serviços de comunicação, informação e entretenimento. Esses serviços estão na gênese da sociedade em rede (CASTELLS, 2001). A copiosa e fecunda análise de Castells sobre a sociedade em rede secunda os argumentos mobilizados por Bell. Desde as décadas de 1980 e 1990 , o conhecimento se tornou um ativo imprescindível, gerador de valor e central para o licenciamento cada vez maior de produtos, serviços e tecnologias. No entanto, para que determinados conhecimentos se tornem ativos, inseridos em modelos de negócios específicos e objeto de intensos fluxos comerciais, foi necessário um investimento público-governamental em inovação. A partir do início da década de 1990, os governos das mais poderosas economias do globo passam a direcionar recursos crescentes para o financiamento das atividades de pesquisa e desenvolvimento que possam resultar em ganhos de valor econômico, potencializando os diversos processos de competitividade já em curso. Esse foi o momento de construção dos principais sistemas nacionais de inovação tecnológica do mundo. Destacam-se, nesse contexto, países como Japão e Coreia do Sul, cujos financiamentos em pesquisa e desenvolvimento resultaram menos na descoberta de novos componentes e artefatos militares (tão comuns desde os primeiros anos do pós-guerra por parte de potências como os EUA e a União Soviética) e muito mais no desenvolvimento de tecnologias de comunicação, informação, semicondutores, aparelhos eletroeletrônicos, automóveis, entre outros.

Em 1990 a Coreia do Sul direcionava menos de 2\% do seu PIB para pesquisa e desenvolvimento, em 1997 esse percentual chegou a aproximadamente 3\% (DODGSON, 2000). Conforme evidencia o Gráfico 3, entre 2000 e 2013, EUA, Alemanha e Reino Unido elevaram paulatinamente os percentuais dos seus PIBs para o financiamento de pesquisa e desenvolvimento. Salta aos olhos, mais uma vez, o exemplo da Coreia do Sul. Única economia que não figura entre as dez principais economias do globo, o pequeno país do leste asiático é o que mais investe em pesquisa e desenvolvimento, 
ocupando as principais posiçôes entre os países que mais licenciam patentes e copyright, chegando a abrigar hoje a maior fabricante de televisores com software de acesso à internet (smart TV) do mundo e a maior fabricante de dispositivos digitais móveis do globo (smartphones), a Samsung.

\section{Gráfico 3 - Dispêndios em PED em relação ao PIB (2000-20I3) (Em \%)}

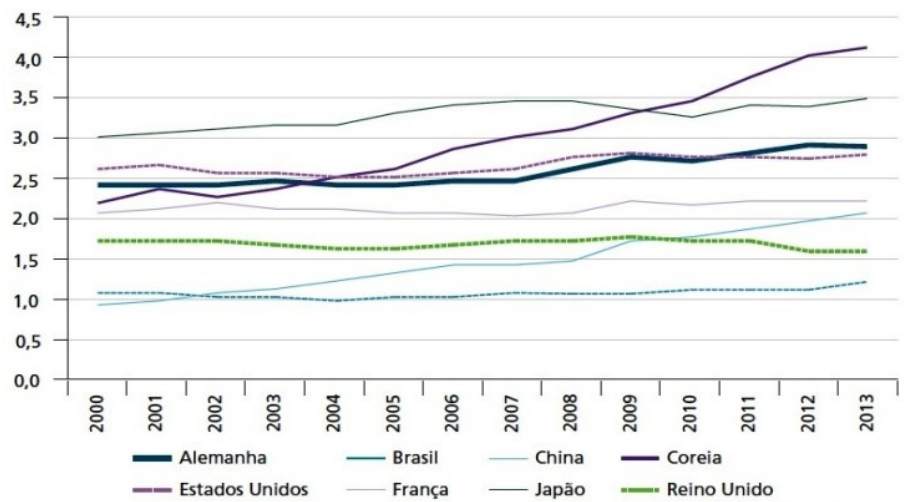

Fonte: IPEA (2017).

Como evidencia o Gráfico 3, os dispêndios em pesquisa e desenvolvimento alcançaram, em 2013, o percentual de 4,2\% do PIB sul-coreano, o que representou a quantia nominal de US\$ 13 bilhóes. Esse aspecto, dentro da série histórica de 1990 a 2013, corroborou diretamente para que a economia sul-coreana saísse de uma posição inteiramente subalterna e dependente nas décadas de 1960 e 1970 para a décima primeira economia do mundo em 2017. No entanto, mesmo investindo em percentuais menores, os valores nominais destinados à pesquisa e ao desenvolvimento por parte de EUA, China e Japão superam em muito os valores nominais observados no caso sul-coreano. Esse aspecto deve-se ao fato de que os valores nominais dos PIBs desses três primeiros são muito superiores aos da Coreia. Os 2,7\% do PIB norte-americano destinado aos investimentos em pesquisa e desenvolvimento se traduziram, em 2013, no astronômico valor de US $\$ 43$ bilhôes (cerca de R $\$ 160$ bilhóes). O mesmo vale para a China. Os 2,1\% do PIB chinês destinados para pesquisa e desenvolvimento significaram, em valores nominais de 2013, US\$ 24 bilhôes. Não por acaso, 
as três principais economias do mundo (EUA, China e Japão), em valores nominais de 2017, também são a que mais possuíam patentes, direitos de propriedade intelectual e copyright. Em 2017 o maior volume de solicitação e registros de patentes foi conferido à China, EUA, Japão e Coreia do Sul, sucessivamente. No mesmo ano, a China já detinha $22 \%$ de todas as patentes relacionadas à inteligência artificial em todo o mundo.

A expansão das sociedades pós-industriais de serviços e a consolidação das economias do conhecimento contribuíram diretamente para a aproximação regular e estrutural entre o domínio estético-simbólico e o domínio econômico-tecnológico nas últimas duas décadas. Foi essa aproximação que, no interior do seu movimento, trouxe consigo o seleto grupo de economistas e o interesse prático-operacional de analisar, conduzir e influenciar essas relaçóes por meio de indicadores, índices, modelos e métricas que, por seu turno, resultaram em políticas econômicas.

\section{A digitalização e expansão dos mercados culturais}

Para que essa aproximação seja devidamente desvelada, mais um caminho reclama tratamento: a digitalização e expansão global dos mercados culturais, processo que optamos por designar como a digitalização do simbólico. Esse processo está lastreado em quatro tendências históricas: i) a intensa elevação do aumento da velocidade, capacidade de armazenamento e transmissão de dados por parte da rede mundial de computadores, potencializada por meio da tecnologia do streaming e da computação em nuvem; ii) a profusão global dos dispositivos digitais móveis (notadamente os smartphones), fabricados por grandes corporaçóes globais como Apple e Samsung; iii) a convergência digital, que conecta diversos dispositivos entre si, múltiplos suportes e linguagens, permitindo o fenômeno transmídia e multitela; iv) e o advento da internet 2.0, etapa da internet por meio da qual a grande maioria dos conteúdos e dados (textos, notícias, vídeos, músicas, mensagens, imagens, etc.) são criadas, compartilhadas e consumidas pelos próprios usuários, engajados nas principais redes sociais digitais do planeta, como Facebook, Instagram, WhatsApp, Youtube e Twitter. Essas quatro âncoras conjugadas penetraram paulatinamente os mercados culturais, redimensionando o processo de criação, produção, distribuição e consumo dos conteúdos artístico-culturais, como livros, músicas, filmes e fotografias. 
As quatro tendências descritas culminam na produção, no consumo e na monetização dos chamados serviços culturais-digitais. Uma canção musical ouvida em um show durante um festival internacional de música diz respeito ao consumo de um bem simbólico, essa mesma canção ouvida e fruída a partir de um serviço digital de assinatura on demand, como as plataformas digitais de streaming Deezer e Spotify, torna-se um serviço cultural-digital. Do mesmo modo, um livro, comprado presencialmente em uma grande livraria (megastore) ou através de um site especializado, e lido a partir do seu suporte físico (papel) diz respeito a um bem cultural. Um livro digital, comprado por meio do site especializado, e lido através de um leitor digital, como o Kindle, da Amazon, torna-se um serviço cultural-digital. Com efeito, as tendências que compóem e tornaram possível o processo de digitalização do simbólico, imprimiram uma aguda migração dos conteúdos que caracterizam os bens culturais para os serviços culturais-digitais.

Alguns mercados culturais se digitalizaram muito mais do que outros. Por exemplo, o mercado fonográfico foi o que experimentou a mais contundente digitalização. Em 2014, conforme dados de International Federation of the Phonografhic (IFPI), 46\% de toda a música consumida no planeta já foi digital, ficando os conteúdos musicais fruídos por meios de suportes físicos com outros $46 \%$ e as performances musicais ao vivo com $8 \%$; além disso, a receita das empresas que oferecem os serviços musicais-digitais se elevou em 39\% (cerca de US\$ 1,5 bilhóes), contribuindo decisivamente para que a esfera digital-musical alcançasse a cifra de US\$ 6,85 bilhóes, ante a US\$ 4,4 bilhóes em 2009 - um aumento de 56\% em apenas seis anos (IFPI, 2015).

Outros mercados, como o mercado de museus e patrimônio, passam também por um processo de digitalização. Por exemplo, ao compartilhar em uma rede social digital uma fotografia/imagem de uma escultura, de um quadro ou de um objeto pertencente ao acervo de um museu em Paris, ou de qualquer outro lugar no mundo, o turista compartilha e faz circular determinado conteúdo junto a seus amigos, familiares e conhecidos. Ao fazê-lo, muito provavelmente por meio de um dispositivo digital móvel, como o smartphone, esse conteúdo desencadeia motivaçóes de visitas presenciais, instaura novos significados e percepçóes sobre o universo dos museus. A profusão dessa prática levou grandes museus globais, como o Louvre, a criar 
serviços-digitais por intermédio dos quais, a distância, os interessados percorrem o acervo digital do museu, trafegando em seus labirintos, salóes e galerias. Esses serviços podem ser fruídos por meio da criação de um avatar pessoal do visitante digital, que, ao se cadastrar, tem acesso a diversas experiências de consumo cultural-digital e, de certo, desencadeia nesses usuários o desejo de experimentar aquele consumo de modo presencial.

Os serviços culturais-digitais abrigam alto grau de inovação de serviços e de produtos, além de ser uma reserva permanente da geração de patentes e copyright. Os quatro mercados culturais-digitais localizados na parte superior da Figura 1 - audiovisual, musical, editorial e publicitário - são os mercados que detêm o maior grau de inovação tecnológica, maior grau de digitalização e o maior nível de convergência digital. São esses os mercados que passaram por uma intensa transição digital e, por conseguinte, por uma maior penetração dos serviços culturais-digitais.

Figura I - Mercados e variáveis do processo de digitalização do simbólico

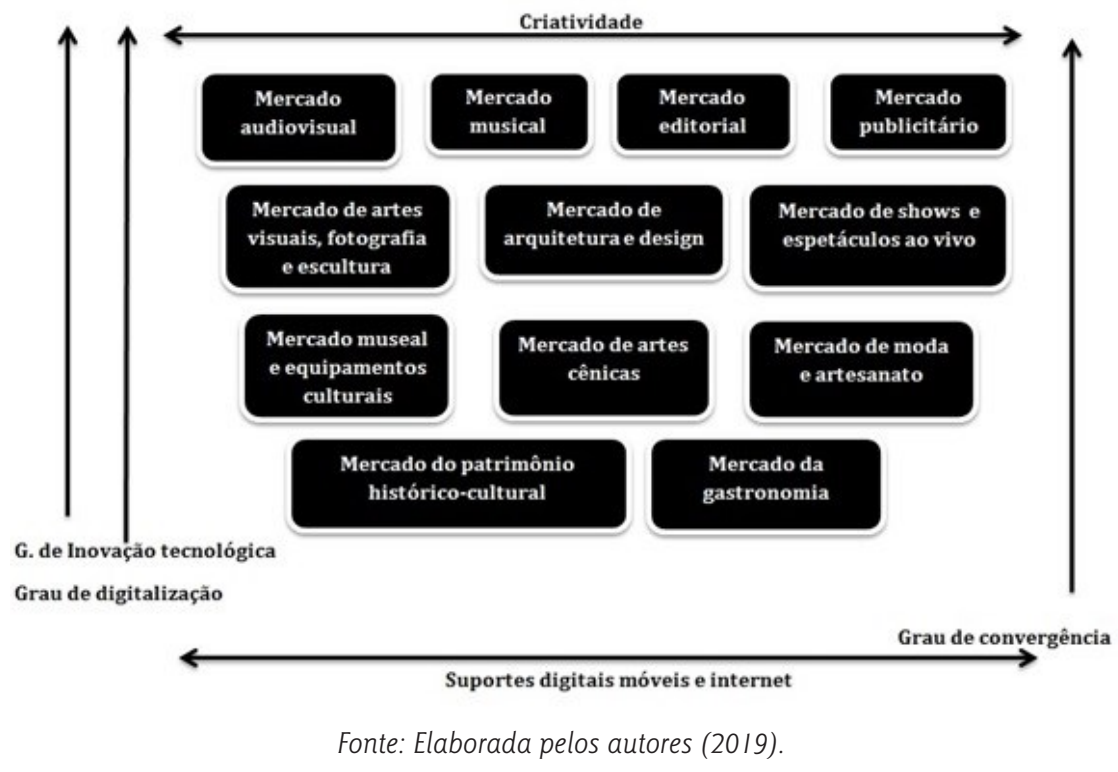

Não por acaso, as maiores companhias mundiais de tecnologia digital são as principais responsáveis pela criação e construção de um modelo de 
negócios em torno dos serviços culturais-digitais. Google, Amazon, Apple e Facebook (GAFA), acompanhadas de Microsoft, contratam, licenciam, distribuem e comercializam os serviços culturais-digitais, adotando o mesmo modelo de negócios e plataformas que concorrem com companhias como Netflix, Deezer, Spotify e outras. A Netflix se tornou uma das empresas mais valorizadas do mundo. A receita operacional líquida da empresa, em 2014, foi de US\$ 5,5 bilhóes; e, em 2010, apenas quatro anos antes, havia sido de US\$ 2,2 bilhôes (NETFLIX, 2018). No primeiro semestre de 2018 a Netflix alcançou a marca de 125 milhóes de assinantes, tornando-se a companhia de mídia com o maior valor de mercado 6 do mundo, avaliada em U\$S 162 bilhóes, superando a Disney, cujo valor de mercado foi avaliado em US\$ 152 bilhóes. De acordo com a própria Netflix, a companhia pretende finalizar 2018 com o investimento de aproximadamente US\$ 8 bilhões na produção de conteúdos originais, revelando a meta de criar e produzir cerca de mil séries e filmes até o final do ano. O Spotify, maior plataforma de streaming de música, possuía, no início de 2018, mais de 55 milhóes de assinantes, bem a frente do seu principal concorrente, a Apple Music, que abarcava cerca de 15 milhóes de assinantes (DIGITAL TRENDS, 2018).

A recente aquisição do grupo Century Fox pela Disney revela a contundência econômica dos serviços culturais-digitais. Em dezembro de 2017 a Disney realizou a aquisição do conglomerado Century Fox por US\$ 52,4 bilhões (BUSINESS INSIDER, 2018). Como consequência da aquisição, a Disney passou a controlar as franquias e o licenciamento de produtos dos conteúdos de X-Men, Avatar, Planetas dos Macacos, Era do Gelo, The Simpsons, Modern Family, Homeland, The Americans, American Horror Story, Empire, This is Us, além de serviços e canais como FX Networks, 20th Century, Fox Television, National Geographic, Fox Sports, Regional Networks, Fox Networks, Group International, Star India, SKY plc, Trata Sky, Endemol Shine Group e Endemol (proprietária dos direitos do Big Brother, Masterchef e da série Black Mirror). Como parte da aquisição, a

\footnotetext{
O valor de mercado é calculado de acordo com o valor das ações da empresa, a projeção de crescimento dos ativos da empresa (neste caso do número de assinantes), os investimentos (neste caso a produção, aquisição e licenciamento de conteúdos) e as perspectivas de crescimento do modelo de negócios (neste caso, as assinaturas mediante as plataformas digitais de streaming).
} 
Disney passou a ser a controladora majoritária da Hulu, uma das principais concorrentes diretas da Netflix. No primeiro semestre de 2018 a Hulu possuía mais de 20 milhóes de assinantes nos EUA. A empresa ainda não atua fora dos limites daquele país.

Com a aquisição, a Disney anunciou que pretende lançar uma plataforma integrada de streaming, oferecendo, mediante assinaturas mensais, a maior carteira diferenciada de conteúdos culturais-digitais do planeta: animação, séries, filmes e esportes. Essa carteira de conteúdos pode ser visualizada no interior dos seis vetores que compóem o mercado audiovisual global: 1) cinema de shopping, 2) internet, 3) vídeo doméstico, 4) games, 5) TV aberta e 6) TV por assinatura. A soma econômica desses vetores faz do mercado audiovisual o maior mercado cultural do planeta. Desse modo, a Disney, um dos maiores estúdios cinematográficos do globo e, portanto, uma companhia com um modelo de negócio fincado na produção e distribuição de bens simbólicos audiovisuais, desloca parte do seu interesse corporativo-criativo para os serviços culturais-digitais de exibição on demand. Com efeito, os mercados culturais tornam-se, cada vez mais mercados culturais-digitais. $\mathrm{O}$ controle econômico e comercial dos serviços culturais-digitais por parte das companhias de tecnologia e por conglomerados tradicionais, como a Disney, recrudesce ainda mais um processo evidenciado por Castells desde os anos de 1980: a aquisiçáo e fusão de corporaçôes e conglomerados de mídia, entretenimento e cultura, resultando em gigantescos oligopólios mundiais.

No interior de cada um dos mercados culturais apresentados anteriormente na Figura 1 (acima), atuam seis agentes - mencionados, a seguir, na Figura 2. Independentemente do mercado cultural ao qual nos refiramos esses seis agentes estarão presentes, atuando de forma mais ou menos clara, para realizar os seus interesses, expandir seus limites de atuação e acomodar eventuais tensôes. São eles: 1) as empresas culturais especializadas; 2) as empresas não culturais; 3) os profissionais criativos especializados e trabalhadores da cultura; 4) os bancos comerciais privados; 5) as instituiçóes estatais-governamentais; 6) os consumidores de conteúdos e bens culturais. As interfaces, as relaçóes e o poder econômico-político exercido por cada um desses agentes depende da dinâmica sociológica mais amplas dos contextos locais, regionais e nacionais. 
Figura 2 - Principais agentes econômicos dos mercados culturais globais e nacionais

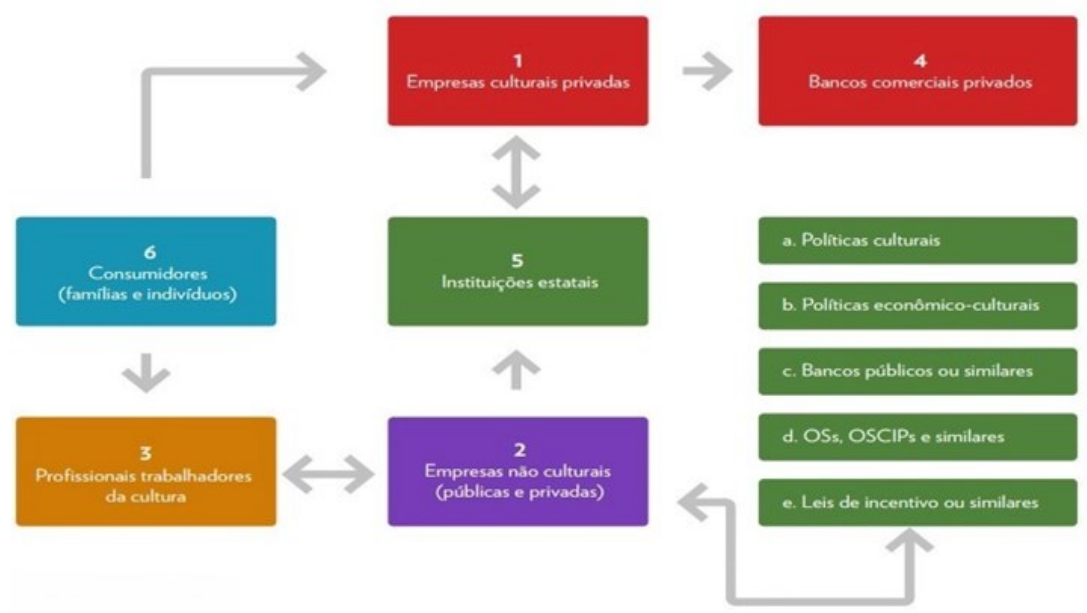

Fonte: Elaborada pelos autores (20/9).

Entre os agentes arrolados na Figura 2, importa explorar aqui apenas um: as instituiçóes estatais-governamentais. Foi por meio da atuação dessas instituiçóes que as categorias de indústrias criativas, economias criativas e cidades criativas se tornaram categorias-forças, manejadas e aplicadas por novos especialistas - economistas, técnicos e consultores convertidos a esses temas - na forma de políticas de desenvolvimento econômico local, regional e nacional.

\section{A triangulação entre Estado, agências transnacionais e economistas na conformação da categoria de economia criativa enquanto recurso de poder}

Com o crescimento das economias pós-industriais de serviços, aliado à consolidação das economias do conhecimento e somando-se, ainda, a fremente digitalização do simbólico, muitos governos nacionais passaram a elaborar e implementar políticas de desenvolvimento voltadas para a expansão dos seus mercados culturais internos e para o aumento das exportaçôes de determinados bens culturais-digitais, como o cinema, a moda, o 
design, a música e a literatura. É exatamente nesse momento que os economistas são recrutados, juntamente com os administradores e os teóricos das escolas de negócios. A rigor, a relevância econômica do audiovisual em muitos países (como Estados Unidos e Inglaterra), assim como a presença marcante do turismo cultural em países como França e Espanha, já havia despertado o interesse acadêmico por parte desses profissionais de estudar tais aspectos. No entanto, somente com os impactos dos setores de serviços, a consolidação da economia do conhecimento e, principalmente, com a penetração do processo de digitalização do simbólico sobre os mercados culturais e seus agentes estruturais é que as categorias-força de induistrias criativas, economia criativa e cidades criativas finalmente assumiram o status de políticas de estado.

Foi o que aconteceu, por exemplo, na Austrália e Inglaterra, onde, em meados da década de 1990, seus governos formularam políticas objetivando elevar a dinâmica econômica, a geração de trabalho e de negócios junto a determinados setores, como o cinema, a moda, o design, a gastronomia, o patrimônio e as artes visuais.

Em 1996, o governo trabalhista do ex-primeiro ministro Tony Blair formulou o mais ambicioso programa de desenvolvimento do que passaria a ser denominado como indústrias criativas. Através do DCMS (Departamento de Cultura, Mídia e Esportes da Inglaterra) objetivou-se, a um só tempo, formular um vasto e complexo programa governamental que permitisse mensurar, valorizar e dinamizar os setores criativos ancorados na proteção e exploração de copyright - música, artes, cinema, patrimônio, arquitetura, design, moda, etc. Desde então, muitos governos e agências transnacionais (Organização das Naçóes Unidas para a Educação, a Ciência e a Cultura (UNESCO), Conferência das Nações Unidas sobre Comércio e Desenvolvimento (UNCTAD), e a Organização Mundial do Comércio (OMC) seguiram a mesma direção. Não tardou até que os resultados dessas açóes começassem a aparecer, assim como inúmeros relatórios globais que demonstravam, de maneira inequívoca, o potencial desses setores. Assim como também não tardou para que os seus teóricos, consultores e planejadores granjeassem notoriedade global, notadamente Richard Chaves, David Thorsby, John Howkins e Richard Florida. 
Em 2001, os relatórios do DCMS, da Inglaterra, demonstraram que a chamada indústria criativa era responsável por $5 \%$ de todo o PIB do Reino Unido e $11 \%$ de toda a mão de obra empregada. O DCMS definia as indústrias criativas como sendo "[...] aquelas indústrias que têm a sua origem na criatividade intelectual, na habilidade e no talento e que possuem um potencial para geração de riqueza e de trabalho através da geração de exploração da atividade intelectual" (INGLATERRA, 1998, p. 5). No rastro dessa definição, muitas outras semelhantes surgiram e ganharam penetração nas agendas governamentais em todo o mundo, desde a Austrália até o Brasil, passando pela Uniâo Europeia e os países asiáticos emergentes, como China e Índia. Esses países criaram estruturas governamentais locais, regionais e nacionais (secretarias, departamentos, ministérios, órgãos de fomento e financiamento, linhas de créditos, programas de capacitação, treinamento especializado, profissionalização, escolas de negócios e cursos de empreendedorismo e gestão) voltados para os temas de indústrias criativas, economia criativa e cidades criativas, assim como financiaram pesquisas e relatórios técnicos com vistas à mensuração desses setores.

Em 2010, a UNCTAD divulgou um relatório assinalando que, mesmo diante da severa crise econômica e financeira de 2007/2008 que produziu uma redução do comércio em 12\% entre 2002 e 2009, os setores criativos cresceram 14,4\% (UNCTAD, 2010). Dois anos depois, a agência produziu um novo relatório, constatando que o fluxo comercial de bens criativos alcançou a cifra de U\$ 624 bilhóes, em 2011, o dobro do alcançado em 2002. Desse total, a taxa média de crescimento foi de $8,8 \%$, chegando a $12,1 \%$ nos chamados países desenvolvidos. A eloquência desses números fez com que, cada vez mais, governos nacionais e agências transnacionais se interessassem pelo tema, aproximando-se dos teóricos/pesquisadores/ consultores que formulam conceitos, índices, indicadores e variáveis acerca da economia criativa e da sua família conceitual ${ }^{7}$.

7 O termo "economia da cultura" foi criado nos anos 1960 por um grupo de economistas que pretendiam avaliar os custos dos espetáculos teatrais (cenários, salários, infraestrutura, aluguel de espaços, entre outros), de modo a mensurar a taxa de retorno desses eventos (FERNÁNDEZ, 20 I 6). O termo permaneceu restrito e pouco conhecido fora dos Estados Unidos, até que as transformações assinaladas estimularam o desenvolvimento $e$ uso de novos termos e novas formas de classificação por parte de especialistas, bem como governos e agências transnacionais, levando a sua consagração como parte desse novo arsenal teórico. 
Os impactos dessas métricas, estatísticas, indicadores, índices, variáveis e modelos de classificação não foram poucos. Basta citar alguns para reunir subsídios suficientes que demonstrem o acúmulo de poder por parte dos economistas, administradores e teóricos das escolas de negócios na consecução de uma nova área técnica, científica e governamental capaz de imprimir novas dinâmicas econômicas às cidades, às regióes e aos países por meio da implementação de políticas e novos investimentos públicos e privados.

Entre 1998 e 2013 surgiram sete modelos de classificação das chamadas indústrias criativas, justificados como capazes de subsidiar a formulação e execução de novas políticas:

1. o modelo DCMS inglês, que classifica a indústria criativa em publicidade, arquitetura, mercado de artes e antiguidades, artesanato, design, cinema, moda, cinema e vídeo, música, artes cênicas, editoração, software, rádio e TV, jogos de vídeo e computadores;

2. o modelo dos textos simbólicos, que estabelece a seguinte classificação: a) as indústrias culturais centrais (publicidade, cinema, internet, editoração, rádio e TV, jogos de vídeos e computadores); b) as indústrias culturais periféricas (artes criativas); c) as indústrias culturais de fronteira (moda, esportes, software e eletrônica de consumo);

3. o modelo dos círculos concêntricos da UNCTAD, que consiste nas artes criativas centrais (literatura, música, artes cênicas e artes visuais), outras indústrias culturais centrais (cinema, museus e bibliotecas) e indústrias relacionadas (publicidade, arquitetura, design e moda);

4. o modelo de copyright da Organização Mundial da Propriedade Intelectual, composto por indústrias de copyright centrais (publicidade, cinema e vídeo, música, artes cênicas, editoração, software, rádio e TV, artes gráficas e visuais), indústrias de copyright interdependentes (materiais de gravação, eletrônica de consumo, instrumentos musicais, papel, fotocopias e fotografias) e indústrias de copyright parciais (arquitetura, vestuário e calçados, desenho gráfico, moda, decoração e brinquedos); 
5. o modelo da UNESCO, composto por indústrias em domínios culturais centrais (museus, galerias e bibliotecas, artes cênicas, festivais, artes visuais, desenho, editoração, rádio e TV, filme e vídeo, fotografia e mídia alternativa) e indústrias em domínios culturais expandidos (instrumentos musicais, equipamentos de som, arquitetura, publicidade, equipamentos de impressão, software e hardware audiovisual);

6. o modelo norte-americano para as artes, compreendido por indústrias culturais de fronteiras: publicidade, arquitetura, serviços de escolas de arte, desenhos, filmes, museus, zoológicos, música, artes cênicas, editoração, rádio e TV, artes visuais;

7. o modelo canadense, composto por mídia escrita, indústria cinematográfica, radiodifusão, gravadoras de som, editoras de músicas, artes cênicas, artes visuais, arquitetura, escultura, fotografia, desenho gráfico, publicidade, museus e galerias de arte, arquivos, bibliotecas e educação cultural.

Salta aos olhos o fato de que os modelos estabelecem clivagens e diferenciaçóes para classificar e hierarquizar setores/mercados. Esse imperativo ocorreu justamente porque as linguagens artísticas, os processos de criação e os mercados culturais-digitais, de um modo geral, foram profundamente penetrados pelos processos de inovação tecnológica e definição do conhecimento como um ativo imaterial imprescindível na nova economia do conhecimento, no interior da qual a criatividade e as práticas que conduzem até a materialização da criatividade em conteúdos tangíveis e intangíveis passaram a ser muito valorizadas comercialmente. Por isso, setores antes vistos como funcionais, como a moda, o design, o software e a publicidade, passaram a figurar no rol de atividades criativas. Os modelos descritos têm efeitos econômicos diretos, pois guiam e orientam a construção e execução de políticas de desenvolvimento.

Os sete modelos descritos subsidiaram, por exemplo, a adoção de açóes e programas na América Latina. No Brasil, o modelo criado e difundido pelo Ministério da Cultura, a partir de 2011, é uma combinação do modelo da UNCTAD com o modelo da UNESCO. Mas há um efeito econômico 
ainda mais direto: a elaboração e execução dos índices de criatividade, que são indicadores e métricas utilizados por cidades, regióes e países para, junto com os modelos descritos, implementar açóes e destinar mais ou menos recursos para economia criativa. Os índices foram criados e sistematizados para criar parâmetros, métricas e guias de investimentos públicos e privados. De acordo com Anita Kon (2016), há onze índices centrais: índice de criatividade de Flórida (FCI); índice de criatividade da comunidade criativa do Silicon Valley (SV-CCI); índice de Euro-Criatividade (F-ECI); índice de criatividade de Hong Kong (HKCI); índice de criatividade Theco (CZCI); índice composto da economia criativa (CICE); índice da cidade criativa (J-CCI); índice europeu de criatividade (ECI); índice de criatividade de Baltimore (BCI); índice da cidade criativa de Landry (L-CCI); índice da cidade criativa ARC (CCI-CCI). No interior desses índices, que funcionam como indicadores de mensuração, foram criadas diversas variáveis. 


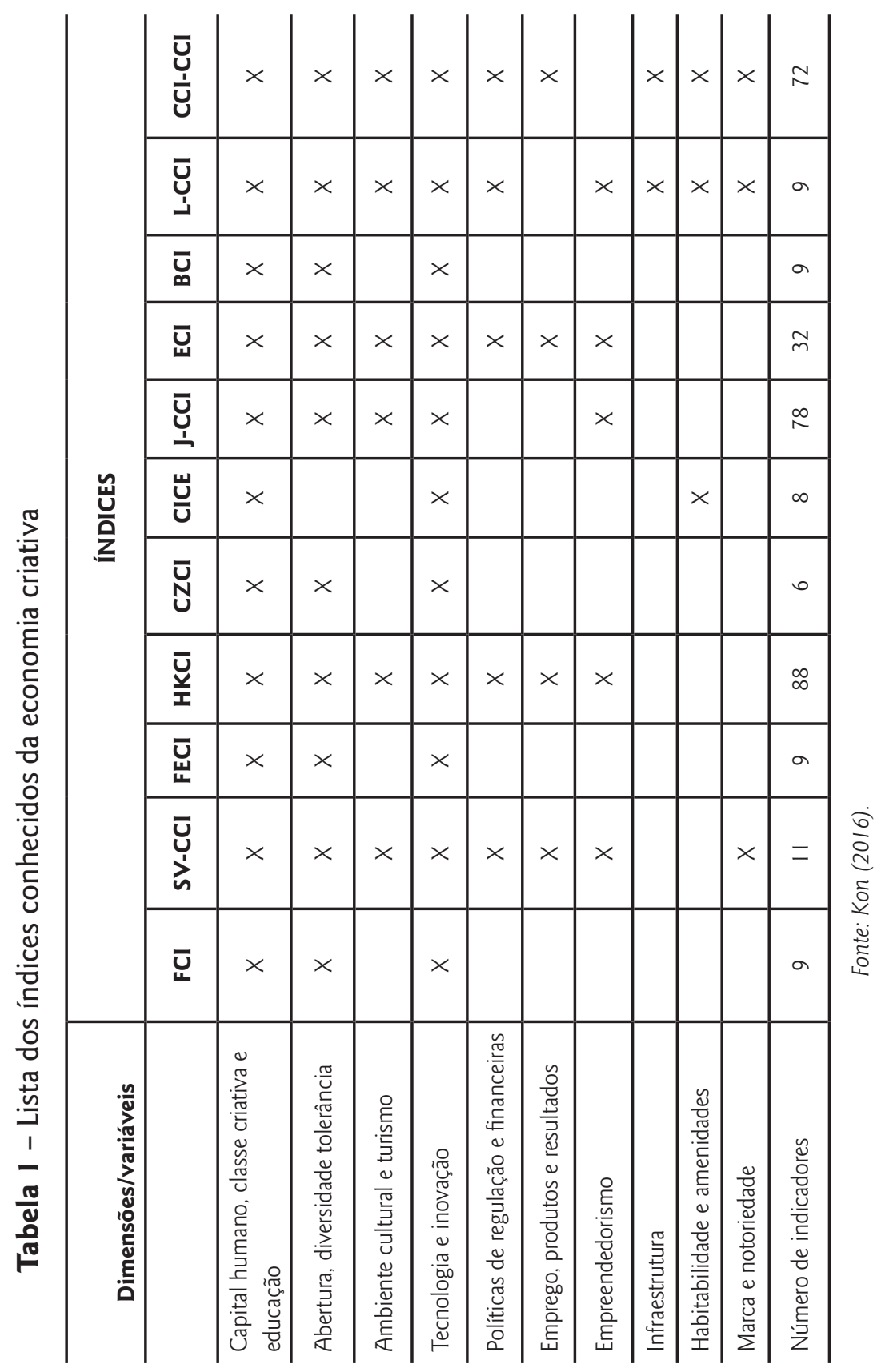


Quem criou os modelos de clivagens, os índices e as variáveis? Os economistas, administradores/gestores públicos e os teóricos das escolas de negócios em relação estreita com os técnicos dos governos nacionais e dos organismos transnacionais. $\mathrm{O}$ mais famoso deles, o índice de criatividade de Flórida (FCI), foi adotado em diversos locais do mundo. O índice foi criado pelo economista e cientista político Richard Flórida e consiste em demonstrar que a construção de uma cidade criativa e de uma economia criativa decorre da profusão de três dimensões socioculturais que estimulam e são imprescindíveis para se criar a criatividade, o modelo dos três Ts: tecnologia, talento e tolerância (FLÓRIDA, 2015). O impacto técnico- político desses modelos de classificaçáo resultou em um impacto ainda mais potente no domínio econômico, cujas políticas de desenvolvimento passaram incorporar a categoria-força da economia criativa.

Esse aspecto autoriza sustentar que as categorias-forças de economia criativa, indústrias criativas são categorias nativas, construídas, manejadas e aplicadas por instituiçóes governamentais, redes empresariais, organizaçôes transnacionais e escolas de negócios com vistas a delinear uma nova área de interesse governamental, empresarial e técnico. A categoria, e toda a sua engenharia técnico-operacional, serve como um cardápio de aplicação prática por governos, empresas, instituiçóes e escolas de negócio. Por exemplo, no Brasil, os principais estudos, dados e classificaçóes acerca das indústrias criativas foram criados e difundidos por uma entidade empresarial privada, a Federação das Indústrias do Estado do Rio de Janeiro (FIRJAN), que dispóe do seu próprio modelo classificatório e relatórios de estudos, e não por um centro acadêmico ou uma instituição universitária, tampouco por um instituto estatal de pesquisa, como o Instituto Brasileiro de Geografia e Estatística (IBGE) e o IPEA.

Esses aspectos diferenciam muito as categorias nativas das categorias analíticas, engendradas com o propósito de compreender e explicar as relações contraditórias, tensas e ambivalentes entre o domínio estético-simbólico e o domínio econômico-tecnológico, como foi o caso de conceitos como indústria cultural - Adorno e Horkheimer (1985), materialismo cultural-Raymond Williams (2011) ou economia de signos e espaços - Lash e Urry (1993), dentre outros. Esses conceitos não serviam aos mesmos fins 
prático-operacionais a que se destinam os conceitos de economias criativas, indústrias criativas e cidades criativas. Contudo, os usos político-econômicos e os efeitos práticos dos últimos podem ser analisados e explicados por meio de conceitos científicos como os primeiros.

Para os fins deste trabalho, propóe-se o uso da categoria analítico-descritiva de mercados culturais-digitais. É precisamente aqui que podemos fazer uso dessa categoria para sustentar a nossa principal hipótese: as políticas públicas de desenvolvimento econômico inspiradas nas categorias-força de indústrias criativas, economia criativa e cidades criativas conduziram as instituiçóes governamentais e estatais ainda mais para o centro dos mercados culturais, que, cada vez mais, como se viu, se tornam mercados culturais-digitais.

Como evidenciado na Figura 2, as instituiçóes governamentais-estatais estão localizadas hoje no centro dos mercados culturais, pois dinamizam as empresas culturais privadas por meio de empréstimos públicos regulares, assim como criam políticas de formação e especialização para os trabalhadores da cultura e os profissionais criativos, além de, por meio de leis e mecanismos de incentivos fiscais, financiarem e patrocinarem eventos e atividades artístico-culturais. A construção e implementação de políticas econômicas e culturais norteadas pelo conceito nativo de economia criativa e suas homólogas resultou na dinamização e complexificação dos mercados culturais, principalmente, os mercados "criativo-funcionais" e suas cadeias de valor, como os mercados de designer, moda, publicidade e games, marcados por um alto grau de digitalização e inovação tecnológica. Além dos modelos de classificação e dos índices, salta também aos olhos a profusão de relatórios técnicos no Brasil e no mundo (conforme demonstrado na Tabela 2, logo a seguir), que ganharam bastante visibilidade técnica e política nos últimos dez anos, nos quais os economistas/consultores contribuíram diretamente para a sua feitura. 
Tabela $\mathbf{2}$ - Principais relatórios governamentais, corporativos e de agências transnacionais - dados e indicadores sobre economia criativa - Brasil e mundo

\begin{tabular}{|c|c|c|c|}
\hline Tabela 2 & Ano & Título & Escopo \\
\hline $\begin{array}{l}\text { Comissão } \\
\text { Europeia }\end{array}$ & 2013 & $\begin{array}{c}\text { Special Cultural Access } \\
\text { and Participation Report - } \\
\text { Eurobaroter } 399\end{array}$ & $\begin{array}{l}\text { Evidencia as práticas de consumo cultural dos } \\
27 \text { países-membros da União Europeia, como } \\
\text { a frequência aos equipamentos culturais, tais } \\
\text { como cinemas, livrarias, teatros e museus }\end{array}$ \\
\hline $\begin{array}{l}\text { Cultural } \\
\text { Statistics } \\
\text { Eurostat }\end{array}$ & 2011 & Comissão Europeia & $\begin{array}{l}\text { Material de estatística descritiva sobre as } \\
\text { diversas dimensões dos mercados culturais } \\
\text { europeus: trabalho, empresas, subsídios } \\
\text { governamentais, financiamento, exportação e } \\
\text { importação }\end{array}$ \\
\hline Unesco & 2015 & $\begin{array}{l}\text { Cultural Times - The First } \\
\text { Global Map of Cultural and } \\
\text { Creative Industries (2015) }\end{array}$ & $\begin{array}{l}\text { Mapeamento global dos setores econômicos e } \\
\text { culturais da indústria criativa no mundo }\end{array}$ \\
\hline Unesco & 2016 & $\begin{array}{l}\text { Institute for Statistics } \\
\text { - The Globalisation of } \\
\text { Cultural Trade: a Shift in } \\
\text { Consumption }\end{array}$ & $\begin{array}{l}\text { Material minucioso acerca do fluxo de } \\
\text { comércio global entre diversos países do } \\
\text { mundo, envolvendo os bens e serviços } \\
\text { culturais. Traz uma metodologia nova } \\
\text { acerca do fluxo de exportação e importação, } \\
\text { diferenciando bens culturais de serviços } \\
\text { culturais }\end{array}$ \\
\hline $\begin{array}{l}\text { IFPI Digital } \\
\text { Music Report }\end{array}$ & 2015 & Deezer & $\begin{array}{c}\text { Apresenta a expansão dos serviços de } \\
\text { streaming, especialmente dos serviços } \\
\text { musicais, e o panorama global da digitalização } \\
\text { da música }\end{array}$ \\
\hline SECOM-BR & 2016 & Pesquisa Brasileira de mídia & $\begin{array}{l}\text { Dados sobre o consumo de mídia no Brasil: } \\
\text { rádio, TV, revistas, jornais, internet e cinema. }\end{array}$ \\
\hline CGIB & 2017 & $\begin{array}{c}\text { Cultura e tecnologia } \\
\text { no Brasil: estudo sobre } \\
\text { as práticas culturais da } \\
\text { população e o uso das } \\
\text { tecnologias da informação e } \\
\text { comunicação }\end{array}$ & $\begin{array}{l}\text { Dados sobre o consumo de conteúdos } \\
\text { tecnológicos, digitais e culturais mediante as } \\
\text { plataformas digitais e suas mediações. }\end{array}$ \\
\hline $\begin{array}{l}\text { IBGE-PNAD } \\
\text { TICs }\end{array}$ & 2017 & $\begin{array}{l}\text { Acesso à internet e à } \\
\text { televisão e posse de telefone } \\
\text { móvel celular para uso } \\
\text { pessoal }\end{array}$ & $\begin{array}{c}\text { Consumo, gastos e dispêndio das famílias e } \\
\text { dos grupos referentes aos conteúdos culturais- } \\
\text { digitais no Brasil }\end{array}$ \\
\hline
\end{tabular}




\begin{tabular}{|c|c|c|c|}
\hline Tabela 2 & Ano & Título & Escopo \\
\hline CETIC & 2017 & $\begin{array}{l}\text { Pesquisa Sobre o Uso das } \\
\text { Tecnologias de Informação } \\
\text { e Comunicação nos } \\
\text { Equipamentos Culturais } \\
\text { Brasileiros }\end{array}$ & $\begin{array}{c}\text { Uso e gestão das tecnologias da informação e } \\
\text { da comunicação nos equipamentos culturais } \\
\text { brasileiros }\end{array}$ \\
\hline FGV & 2016 & $\begin{array}{l}\text { A cultura na economia } \\
\text { brasileira }\end{array}$ & $\begin{array}{c}\text { Dados sobre o impacto econômico dos bens e } \\
\text { serviços atividades e culturais }\end{array}$ \\
\hline IBGE & 2016 & $\begin{array}{l}\text { Pesquisa de Informações } \\
\text { Estaduais e Municipais } \\
\text { básicas - suplemento } \\
\text { Cultura }\end{array}$ & $\begin{array}{l}\text { Dados acerca da gestão, recursos, gastos/ } \\
\text { investimentos sobre políticas culturais no Brasil }\end{array}$ \\
\hline $\begin{array}{l}\text { UFRGS/ } \\
\text { MINC }\end{array}$ & 2017 & $\begin{array}{l}\text { Atlas econômico da cultura } \\
\text { brasileira }\end{array}$ & $\begin{array}{l}\text { Dados, reflexões acerca dos principais setores, } \\
\text { mercados e agregados da economia criativa } \\
\text { no Brasil }\end{array}$ \\
\hline FIRJAN & 2017 & $\begin{array}{l}\text { Mapeamento da indústria } \\
\text { criativa no Brasil }\end{array}$ & $\begin{array}{c}\text { Dados, tipologias e conceituações sobre a } \\
\text { economia criativa no Brasil. }\end{array}$ \\
\hline IPEA & $\begin{array}{c}2014 b, \\
2016\end{array}$ & $\begin{array}{l}\text { Panorama da economia } \\
\text { criativa no Brasil }\end{array}$ & $\begin{array}{c}\text { Dados sobre setores e segmentos da economia } \\
\text { criativa brasileira }\end{array}$ \\
\hline IPEA & $2014 a$ & $\begin{array}{c}\text { Dossiê Regiões } \\
\text { metropolitanas brasileiras }\end{array}$ & $\begin{array}{l}\text { Dados, indicadores, leis e referências acerca das } \\
\text { regiões metropolitanas brasileiras }\end{array}$ \\
\hline ANCINE & $2017 \mathrm{~b}$ & $\begin{array}{l}\text { Serviços de exportação de } \\
\text { bens audiovisual brasileiro }\end{array}$ & $\begin{array}{c}\text { Dados sobre a circulação e a exportação de } \\
\text { serviços audiovisuais brasileiros }\end{array}$ \\
\hline ANCINE & $2017 a$ & $\begin{array}{l}\text { Anuário estatístico do } \\
\text { cinema brasileiro }\end{array}$ & $\begin{array}{l}\text { Dados sobre produção, exibição, circulação e } \\
\text { consumo do cinema brasileiro. }\end{array}$ \\
\hline $\begin{array}{l}\text { BRITISH } \\
\text { COUNCIL }\end{array}$ & 2010 & $\begin{array}{l}\text { Guia prático para o } \\
\text { mapeamento das indústrias } \\
\text { criativas }\end{array}$ & $\begin{array}{c}\text { Dados, definições e orientações para os } \\
\text { estudos realizados acerca das indústrias } \\
\text { criativas. }\end{array}$ \\
\hline
\end{tabular}

Fonte: Elaborada pelos autores (2019).

Ao se instalar no centro dos mercados culturais digitalizados, as políticas públicas direcionadas à categoria-força de economia criativa, conduzidas e executadas pelas instituiçôes estatais, instauraram um novo domínio técnico-operacional. Esse domínio - que envolve os índices, indicadores e relatórios sobre a economia criativa nos mais diferentes lugares, regióes e países - foi criado e povoado pelos economistas, administradores e teóricos-consultores. Desse modo, o interesse do estado 
pela categoria-força de economia criativa trouxe consigo os economistas/ administradores/consultores e, com eles, uma nova autoridade, devidamente acompanhada por um novo regime de competência e uma nova modalidade de poder simbólico.

Para que esses aspectos fiquem claros, é necessário esquadrinhar os labirintos entre os mercados culturais e as distintas políticas públicas direcionadas para o domínio estético-simbólico. Os índices, os indicadores, os relatórios técnicos e, principalmente, os programas, os projetos e as açóes inspirados na categoria-força de economia criativa evidenciam que as instituiçóes governamentais estão no centro dos mercados culturais-digitais globais. Pela primeira vez na história do capitalismo, de modo regular e inequívoco, os mais poderosos Estados nacionais do planeta têm escolhido os setores artísticos, culturais, de entretenimento, comunicação e lazer como parte constitutiva das suas principais políticas econômicas e estratégias de desenvolvimento.

Para secundar essa assertiva, é necessário localizar as políticas direcionadas pela categoria de economia criativa no escopo das políticas de investimento cultural. O investimento cultural público concerne aos recursos financeiros, técnicos e operacionais implicados na elaboração e execução das políticas culturais públicas. São, portanto, recursos que estão sujeitos aos sistemas estatais e jurídicos de controle e obedecem ao processo decisório de instâncias políticas da sociedade civil. Em geral, possuem dois objetivos centrais: 1) promover o acesso à cultura (principalmente local e nacional), contribuindo para a realização dos direitos culturais; 2) financiar a competitividade, os processos de inovação e expansão das pequenas, médias e grandes empresas culturais. As diversas modalidades, combinaçóes e ramificações financeiras e jurídicas existentes em países como Brasil, México, os países da União Europeia e os Estados Unidos permitem sustentar que o investimento cultural público é composto por duas grandes dimensóes: 1) as políticas culturais e 2) os empréstimos financeiros realizados por bancos públicos e/ou bancos nacionais de desenvolvimento. No que tange à primeira dimensão, podemos dividi-la em dois eixos: 1) políticas culturais e 2) políticas econômico-culturais. Essa última corresponde à relevância assumida pelas políticas que buscam dinamizar os arranjos e as cadeias produtivas de cultura, o apoio à incubação e à aceleração das micro e 
pequenas empresas culturais, ao empreendedorismo cultural e os estímulos à construção dos chamados distritos criativos. Os dois eixos abarcam uma grande diversidade de formatos de financiamento das políticas culturais públicas: a) recursos para as políticas culturais locais, regionais e nacionais, previamente aprovadas e destinadas aos órgãos da administração cultural pública (secretarias, ministérios, conselhos, departamentos, agências, etc.); b) a consecução de fundos públicos descentralizados e setoriais (teatro, museus, artes visuais, patrimônio, audiovisual etc.), que recebem recursos de outros setores governamentais (educação, comunicação e turismo); c) fundos públicos e setoriais decorrentes dos impostos arrecadados junto às loterias; d) fundaçóes governamentais e/ou Organizaçóes Sociais (OSs) e Organizaçôes da Sociedade Civil de Interesse Público (Oscips), criadas, na maioria dos casos, para gerir equipamentos culturais públicos (museus, teatros, centros culturais, galerias, entre outros), que recebem recursos governamentais, de empresas públicas (de diferentes setores econômicos) e também doaçôes de pessoas físicas e jurídicas.

Tabela 3 - Composição do investimento cultural público no âmbito dos principais mercados culturais nacionais e globais

\begin{tabular}{|c|c|c|c|}
\hline Natureza & Dimensões & Eixos & Fontes de financiamento \\
\hline $\begin{array}{l}\text { Investimento } \\
\text { cultural } \\
\text { público }\end{array}$ & $\begin{array}{l}\text { Políticas } \\
\text { culturais }\end{array}$ & $\begin{array}{l}\text { Políticas culturais (I) } \\
\text { Recuperação e preservação do } \\
\text { patrimônio (material e imaterial) } \\
\text { Promoção à diversidade cultural } \\
\text { Valorização da identidade } \\
\text { nacional, regional e local } \\
\text { Manutenção dos equipamentos } \\
\text { culturais públicos ou } \\
\text { semipúblicos } \\
\text { Estímulo e apoio à criação de } \\
\text { conteúdos } \\
\text { Manutenção dos grupos, } \\
\text { coletivos e companhias artísticas }\end{array}$ & $\begin{array}{l}\text { Orçamentos repassados aos } \\
\text { órgãos da administração cultural } \\
\text { direta } \\
\text { Fundos públicos setoriais, } \\
\text { compostos por parcelas dos } \\
\text { orçamentos de outros setores } \\
\text { governamentais } \\
\text { Fundos públicos, constituídos } \\
\text { com recursos das loterias } \\
\text { Fundações públicas ou } \\
\text { semipúblicas, gerenciam recursos } \\
\text { dos diferentes níveis de governo } \\
\text { Recursos estatais, doações } \\
\text { individuais e empresariais para } \\
\text { as Organizações da Sociedade } \\
\text { Civil (Oss) e Organizações da } \\
\text { Sociedade Civil de Interesse } \\
\text { Público (Oscips) }\end{array}$ \\
\hline
\end{tabular}




\begin{tabular}{|c|c|c|c|}
\hline Natureza & Dimensões & Eixos & Fontes de financiamento \\
\hline & & $\begin{array}{l}\text { Políticas econômico- } \\
\text { culturais (II) } \\
\text { Incubação de micro e pequenas } \\
\text { empresas, às cadeias produtivas e } \\
\text { aos territórios criativos. } \\
\text { Crédito e estímulo ao consumo } \\
\text { cultural } \\
\text { Estímulo à profissionalização } \\
\text { criativa e ao empreendedorismo } \\
\text { cultural. } \\
\text { Apoio à criação de novos } \\
\text { modelos de negócio, capacitação } \\
\text { empresarial. } \\
\text { Apoio e financiamento à } \\
\text { inovação tecnológica por parte } \\
\text { das empresas culturais } \\
\text { Investimentos em programas e } \\
\text { ações que buscam dinamizar o } \\
\text { turismo cultural local }\end{array}$ & \\
\hline & $\begin{array}{l}\text { Empréstimos } \\
\text { às empresas } \\
\text { culturais } \\
\text { privadas }\end{array}$ & $\begin{array}{l}\text { Crescimento das grandes } \\
\text { empresas e corporações culturais, } \\
\text { expansão dos empregos culturais } \\
\text { e das atividades criativas }\end{array}$ & $\begin{array}{l}\text { Ativos dos bancos comerciais } \\
\text { públicos ou e/ou dos bancos } \\
\text { nacionais ou continentais de } \\
\text { desenvolvimento }\end{array}$ \\
\hline
\end{tabular}

Fonte: Alves (2017).

A nova autoridade dos economistas e o seu regime de competência sedimentando nas duas últimas décadas estão diretamente vinculados à consolidação e institucionalização das políticas econômico-culturais , segundo grande eixo das políticas culturais, no Brasil e no mundo, a partir do final da década de 1990. Como evidencia a Tabela 3, essas políticas ganharam impulso à medida que o categoria-força de economia criativa se consolidou no seio das organizaçóes governamentais de planejamento e desenvolvimento econômico. Ao serem formuladas e implementadas por instituiçôes estatais-governamentais, as políticas direcionadas à economia criativa estão localizadas em um duplo movimento: por um lado, são elas mesmas políticas que resultaram dos desdobramentos assumidos pelos processos de expansão do setor de serviços nas sociedades pós-industriais, do processo de 
consolidação da economia do conhecimento e do processo de digitalização dos principais mercados culturais-digitais do mundo; por outro lado, são políticas que fomentam e estimulam esses mesmos processos.

\section{Conclusão}

O caráter nativo dessa categoria-força fica bastante patente, situado inteiramente na dinâmica de expansão dos mercados culturais-digitais, ao nortear, guiar e justificar a formulação e adoção de políticas econômicas em todo o mundo, cujos principais artífices técnico-científicos dizem respeito a um novo grupo de economistas, denominados de economistas culturais ou economistas da cultura.

Esses aspectos permitem reiterar duas teses centrais a esta reflexão. Primeiramente, o surgimento do categoria-força de economia criativa foi resultado das interfaces e interesses entre um novo e seleto grupo de economistas, os governos nacionais de alguns dos mais poderosos estados-nação e as agências transnacionais do sistema ONU (Organizaçáo das Naçóes Unidas). No entanto, essas interfaces somente ocorreram e os seus interesses se tornaram exequíveis em razão de uma aproximação estrutural entre o domínio estético-simbólico e o domínio econômico-tecnológico. Essa aproximação estrutural foi acelerada e intensificada no decurso das últimas décadas mediante a expansão e consolidação das sociedades pós-industriais de serviços, do advento e recrudescimento da economia do conhecimento e do intenso processo de digitalização do simbólico, cujos efeitos sobre os mercados culturais foram imediatos. Em conjunto, o caráter aplicado da categoria-força de economia criativa, acompanhado de toda uma gramática nova e uma série de recursos técnico-operacionais (modelos, indicadores, índices e métricas), fez com que a sua difusão e legitimação o levassem a se diferenciar em muito das categorias analíticas criadas pelas Ciências Sociais.

Desse modo, a partir da visada teórico-metodológica de autores como Norbert Elias e Pierre Bourdieu (2001), os dados mobilizados neste trabalho autorizam sustentar que - diferentemente da grande maioria dos trabalhos de pesquisa sobre economia criativa, os quais se perguntam sobre a melhor e mais adequada definição conceitual de economia criativa - nos 
perguntamos sobre as diferentes formas de uso político-econômicas do conceito, a sua gênese de elaboração e o regime de poder e autoridade que o acompanha. Com efeito, entendemos que a principal contribuição deste trabalho é demonstrar que as Ciências Sociais, especialmente a Sociologia, dispóem tanto de imaginação conceitual capaz de forjar novas categorias analíticas - como digitalização do simbólico e o capitalismo cultural-digital - como também dispóem de recursos metodológicos e conceituais capazes de compreender e explicar quando, como e por que algumas categorias nativas reivindicam, dentro e fora das Ciências Sociais, o estatuto de categorias de análise, como é exatamente o caso da categoria de economia criativa.

\section{Referências}

ADORNO, T.; HORKHEIMER, M. Dialética do esclarecimento. Rio de Janeiro: Zahar, 1985.

ALVES, E. P. M. Capitalismo cultural-digital: investimento cultural público versus incentivos fiscais. São Paulo: Itaú Cultural, 2017.

BELL, D. Advento da sociedade pós-industrial: uma tentativa de previsão social.São Paulo: Cultrix, 1977.

BOURDIEU, P. O poder simbólico. Rio de Janeiro: Bertrand Brasil, 2001.

BRASIL. Secretaria da Economia Criativa. Relatório de economia criativa 2010: economia criativa uma, opção de desenvolvimento. Brasília: MINC; São Paulo: Itaú Cultural, 2012.

BRASIL. Presidência da República. Secretaria de Comunicação Social. Pesquisa brasileira de mídia - 2016. Brasília: Secretaria de Comunicação Social/PR, 2016.

BRASIL, Agência Nacional do Cinema. Anuário estatístico do cinema brasileiro. Brasília: ANCINE, 2017a.

BRASIL. Agência Nacional do Cinema. Serviços de exportaçáo de bens audiovisual brasileiro. Brasília: ANCINE, 2017b.

BRASIL. Comitê Gestor da Internet no Brasil. Cultura e tecnologia no Brasil: estudo sobre as práticas culturais da população e o uso das tecnologias da informação e comunicação. Brasília: CGI-BR, 2017c.

BRASIL. Comitê Gestor da Internet no Brasil. Pesquisa Sobre o Uso das Tecnologias de Informação e Comunicação nos Equipamentos Culturais Brasileiros. Brasília: CGI-BR, 2017d.

BRASIL. Ministério da Cultura. Atlas econômico da cultura brasileira. Brasília: MINC, 2017e.

British Council. Guia prático para o mapeamento das indústrias criativas. Londres: British Council, 2010. (Série Economia Criativa e Cultural). 
BUSINESS INSIDER. 2018. Disponível em: https://www.businessinsider.com/major-filmfranchises-that-disney-will-own-after-fox-deal-2018-7. Acesso em: 12 dez. 2018.

CASTELLS, M. A sociedade em rede. São Paulo: Paz e Terra, 2001.

CONFERÊNCIA DAS NAÇÓES UNIDAS SOBRE COMÉRCIO E DESENVOLVIMENTO (UNCTAD). Creative Economy Report 2010. Genebra: Unctad, 2010.

DODGSON, M. The management of technological innovation. Oxford: Oxford University Press, 2000.

DIGITAL TRENDS. 2018. Disponível em: https://www.digitaltrends.com/music/apple-music-vsspotify/. Acesso em: 12. dez. 2018.

DODGSON, M. The management of technological innovation. Oxford: Oxford University Press, 2000.

ELIAS, N. A sociedade dos indivíduos. Rio de Janeiro: Jorge Zahar, 1994.

FEDERAÇÃO DAS INDÚSTRIAS DO ESTADO DO RIO DE JANEIRO (FIRJAN). Mapeamento da indústria criativa no Brasil. Rio de Janeiro: FIRJAN, 2016.

FERNÁNDEZ, R. Culture and economics. The New Palgrave Dictionary of Economics. Londres: Palgrave Macmillan, 2008. Disponível em: https://link.springer.com/referenceworkentr y/10.1057\%2F978-1-349-95121-5_2192-1. Acesso em: 12 dez. 2018.

FLÓRIDA, R. The flight of the creative class: the new global competition. Nova Iorque: Harper Businnes, 2005.

FUNDAÇÃO GETÚLIO VARGAS (FGV). A cultura na economia brasileira. Rio de Janeiro: Editora FGV, 2016.

INGLATERRA. Departamento de Cultura, Esportes e Midia. Creative Industries Mapping. Londres: DCMS, 1998.

INTERNATIONAL FEDERATION OF THE PHONOGRAPHIC INDUSTRY. Digital Music Report. Londres: IFPI, 2015.

INSTITUTO BRASILEIRO DE GEOGRAFIA E ESTATÍSTICA (IBGE). Pesquisa de Informaçóes Estaduais e Municipais básicas - suplemento Cultura. Rio de Janeiro: IBGE, 2016. INSTITUTO BRASILEIRO DE GEOGRAFIA E ESTATÍSTICA (IBGE). Acesso à internet e à televisáo e posse de telefone móvel celular para uso pessoal. PNAD TICs. Rio de Janeiro: IBGE, 2017.

INSTITUTO DE PESQUISA ECONÔMICA APLICADA (IPEA). Dossiê Regióes metropolitanas brasileiras. Brasília: IPEA, 2014a.

INSTITUTO DE PESQUISA ECONÔMICA APLICADA (IPEA). Panorama da economia criativa no Brasil. Brasília: IPEA, 2014 b. 
"Economia criativa" como categoria nativa: a atuação dos economistas e as condições de legitimação de um novo recurso de poder | Elder Maia Alves; Bruno Gontyjo do Couto

INSTITUTO DE PESQUISA ECONÔMICA APLICADA (IPEA). Panorama da economia criativa no Brasil. Brasília: IPEA, 2016.

INSTITUTO DE PESQUISA ECONÔMICA APLICADA (IPEA). Radar: tecnologia, produção e comércio exterior. IPEA, 2017.

KON, A. Sobre a cadeia de economia criativa no Brasil: potencial e desafios. Revista de Economia Política, São Paulo, n. 1, v. 36, p. 168-189, mar. 2016.

LASH, S.; URRY, J. Economies of signs and space. Londres: TCS, 1993.

NETFLIX. 2018. Disponível em: https://ir.netflix.com/financials/quarterly-earnings/default.aspx. Acesso em: 12. dez. 2018.

ORGANIZAÇÃO DAS NAÇÓES UNIDAS PARA A EDUCAÇÃO, A CIÊNCIA E A CULTURA (UNESCO). Cultural Times: the First Global Map of Cultural and Creative Industries. Paris: Unesco, 2015.

ORGANIZAÇÃO DAS NAÇÓES UNIDAS PARA A EDUCAÇÃO, A CIÊNCIA E A CULTURA (UNESCO). The Globalization of Cultural Trade, a Shift in Consumption. Paris: Unesco, 2016.

SERVIÇO BRASILEIRO DE APOIO ÀS MICRO E PEQUENAS EMPRESAS (SEBRAE). Sistema de indicadores econômicos dos territórios. Disponível em: http://www.sebrae.com.br/ sites/PortalSebrae/bis/sistema-de-indicadores-economicos-dos-territorios,92a87b008b103410Vgn VCM100000b272010aRCRD. Acesso em: 12. dez. 2018.

UNIÃO EUROPEIA. European Statistical Office. Cultural Statistics. Luxemburgo: UE, 2011.

WEBER, M. Metodologia das ciências sociais. São Paulo: Cortez, 2001.

UNIÃO EUROPEIA. European Statistical Office. Special Cultural Access and Participation Report - Eurobaroter 399. Luxemburgo: UE, 2011.

WILLIAMS, R. Palavras-chave: um vocabulário de cultura e sociedade. São Paulo: Boitempo, 2007.

WILLIAMS, R. Cultura e materialismo. São Paulo: UNESP, 2011.

\section{"Creative economy" as a native category: economists and the legitimation of a new resource of power}

\section{Abstract}

In the last decades, the themes of creative economy, creative industries and creative cities served as a technical and operational fundament for the formulation and execution of a series of economic development public policies. The main actors of this profusion and legitimation of power were the economists, managers and business schools theorists in close relation to national governments 
and UN agencies. This process was possible due to the emergence of post-industrial societies, the expansion of the knowledge economy and the digitalization of cultural markets. The combination of these three aspects produced a structural approximation between the symbolic-aesthetic domain and the economic-technological domain, resulting in the formation of native categories, such as creative economy, creative industries and creative cities. These categories do not have the analytical and descriptive potential which able to comprehend and explain the new relations between those domains, tough they are themselves a result of these new relations.

Keywords: Creative economy. Cultural markets. Native categories. Economists.

Recebido em: 03/06/2018 Aprovado em: 26/03/2019 